\title{
MUSNED EBU-DAVUDA ET-TAJALISIJA (133 - 204. po H., tj. 750 - 819. god.)
}

\section{Sažetak}

Hadis ili sunnet je drugi izvor islamskog prava. Njemu se pridavala važnost još od vremena Allahovog Poslanika, s.a.v.s., preko najodabranije generacije - ashaba, r.a., zatim tabi'ina, i tako sve do današnjih dana. Čuvanje hadisa je prošlo kroz razlicite periode; prvo se hadis pamtio napamet, ali zbog bojazni njegovog zaborava vrlo rano se počelo i sa pisanjem hadisa. Procedura njegovog sakupljanja, bilježenja i popisivanja u razlicite hadiske zbirke je takoder prošla razne faze i periode. Rezultat toga je nastanak različitih hadiskih zbirki: musneda, muvetta'a, musannefa, sunena, sahiha, džami'a, mustahredža, mustedreka i raznih drugih hadiskih zbirki u koje su njihovi autori bilježili ono što je vjerno preneseno od Allahovog Poslanika, s.a.v.s.

Mecu prvim hadiskim zbirkama bili su musnedi, tj. zbirke hadisa u kojima su autori zabilježene hadise razvrstavali po imenima ashaba koji dotične hadise prenose od Vjerovjesnika, s.a.v.s., a ashabe, r.a., bi obično redali po njihovim prednostima $i$ zaslugama koje su učinili tokom svog života. Uobičajeni redoslijed ashaba u mesnedima je da se počne sa desetoricom ashaba kojima je obećan Džennet, zatim učesnici bitke na Bedru, ashabi koji su prisustvovali ugovoru na Hudejbiji i tome slično.

Od prvih musneda koji su nastali i sačuvani su do današnjih dana je Musned Ebu-Davuda Et-Tajalisija, čiji se autor, kao i sama hadiska zbirka, ubraja medu najpoznatije i najpouzdanije knjige te vrste.

Ključne riječi: hadiske zbirke, musned, Ebu-Davud et-Tajalisi, sened

${ }^{1}$ Islamski pedagoški fakultet u Bihaću 


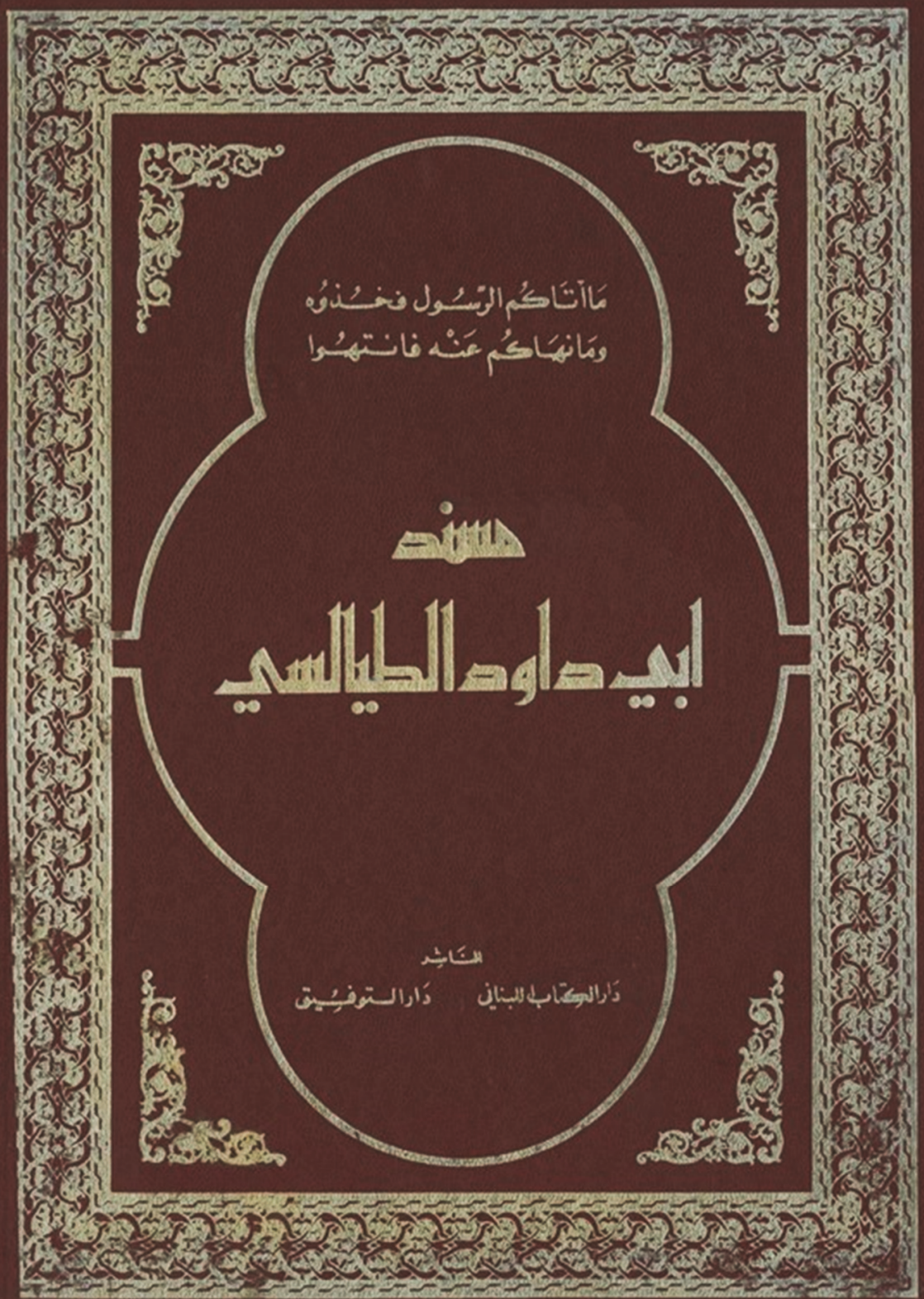




\section{Uvod}

Hvala Allahu, dž. š., koji nam je poslao pejgambera Muhammeda, s.a.v.s., preko kojeg su nam došli Kur'an i sunnet, kao dva glavna izvora islamskog prava. Neka je salavat i selam na njega, njegovu časnu porodicu, njegove ashabe i sve one koji su uložili nesebičan trud $\mathrm{u}$ pamćenju, čuvanju, prenošenju, sabiranju i bilježenju hadisa.

Hadis ili sunnet je drugi izvor islamskog prava. Allah, dž. š., je od prvih stoljeća islama podario Muhammedovom, s.a.v.s., ummetu učenjake koji su se posvetili izučavanju te oblasti, štiteći hadis od podvala onih koji su pokušali u njega ubaciti ono što njemu ne pripada i želeći time ubaciti smutnju i razdor među muslimanima. Glavni teret u tome su ponijele prve generacije ashaba, r.a., zatim tabi'ina, i tako sve do današnjih dana. Hadis se čuvao prolazeći kroz različite periode; prvo se hadis pamtio napamet, ali zbog bojazni od njegovog zaborava, vrlo rano se počelo i sa pisanjem hadisa. Posebna oblast u hadiskoj nauci je raznovrsnost njegovog sakupljanja i bilježenja u hadiske knjige. U prvo vrijeme su se hadisi sakupljali i bilježili bez obzira na njihovu vjerodostojnost ili onoga ko je datu izreku rekao, što znači da su se u iste zbirke bilježili i sahih/pouzdani, hasen/dobri i daiflslabi hadisi, kao što su se u istim zbirkama bilježile izreke samog Poslanika, s.a.v.s., merfu' hadisi, izreke ashaba, mevkuf predaje i izreke tabi'ina i onih poslije njih, maktu' predaje.

Nakon toga, učenjaci počinju odvajati pouzdane hadise u sahih zbirke (poput Buharije, Muslima, Ibn-Huzejme, Ibn-Hibbana, Hakima u Musredreku i tome slično), odvajati hadise koji u sebi sadrže fikhske propise u sunene, sastavljati zbirke koje u sebi sadrže pored Poslanikovih, s.a.v.s., izreka i izreke ashaba i tabi'ina, tzv. musannefi (Abdurrezak i Ibn Ebi Šejbe) i tako dalje, pa sada imamo kompletnu lepezu hadiskih zbirki. Zavisno od poretka hadisa u njima, ili vrsti hadisa koje u sebi sadrže, kao i drugih specifičnosti, ove zbirke nose različite nazive, kao što su: musnedi, muvetta'i, musannefi, suneni, sahihi, ď̌ami'i, mustahredži, mustedreki. 
Među prvim hadiskim zbirkama koje su nastale su musnedi o kojima ćemo nešto više kazati u narednim redovima, a posebno o Musnedu EbuDavuda et-Tajalisija.

\section{Definicija musneda - تعريف المسند}

Musned (ar. ono što je preneseno sa senedom, tj. lancem prenosioca) je među prvim hadiskim zbirkama i smatra se da je neuobičajenog redoslijeda, jer nije tematski poredan. Naime, autor musneda hadise koje je uvrstio u svoju hadisku zbirku obično razvrstava po ashabima koji dotične hadise prenose od Vjerovjesnika, s.a.v.s., bez obzira kakva je vjerodostojnost tih hadisa (sahib/pouzdan, hasen/dobar ili da'iflslab). Redoslijed tih ashaba, r.a., je uglavnom po njihovim prednostima $\mathrm{i}$ zaslugama koje su učinili tokom svog života, pa se obično počinje sa desetoricom ashaba kojima je obećan Džennet/ašsere mubeššreheh. Ponekad je redoslijed po poznatim plemenima, ili po prednosti prelaska na islam, ili po učesnicima bitke na Bedru, ili po ashabima koji su prisustvovali ugovoru na Hudejbiji. Ponekad su u musnedima ashabi poredani i po alfabetu (kao što je to učinio Taberani u svom Velikom mu'džemu) i tome slično. Nekada autor sakupi hadise samo jednog od ashaba, kao što je musned Ebu-Bekra, r.a., ili hadise jedne skupine ashaba, kao npr. musned četvorice halifa, ili musned desetorice kojima je obećan Džennet, ili musned određene skupine ashaba, kao što je musned ashaba koji su prenijeli mali broj hadisa, ili musned ashaba koji su posjetili Egipat i tome slično. $^{2}$

Od prvih musneda koji su nastali i sačuvani (dio koji je od njega sačuvan) su do današnjih dana jeste Musned Ebu-Davuda et-Tajalisija, čiji se autor, kao i sama hadiska zbirka, ubraja među najpoznatije i najpouzdanije knjige te vrste.

${ }^{2}$ El-Kettani, Er-Risaletul-mustatrefe, str. 61. 


\section{Biografija autora:}

Pravo ime Ebu-Davuda et-Tajalisija je: Sulejman ibn Davud ibn ElDažarud Ebu-Davud et-Tajalisi, El-Farisi, El-Basri, El-Esedi, Ez-Zubejri. Poznat je po svom kun-jetu/nadimku: Ebu-Davud, ali se uz to obavezno dodaje Et-Tajalisi. Ovaj dodatak njegovom imenu znači: tajlesan, tj. turban $s$ jednim opuštenim krajem, ${ }^{3}$ obavezno se dodaje kako bi se njegovo ime razlikovalo od jednog od autora šest najpoznatijih hadiskih zbirki/kutubu sitte, Ebu-Davuda es-Sidžistanija (umro 275. godine po H.)

Et-Tajalisi koji je perzijskog porijekla, rođen je 133. godine po Hidžri (tj. 750. godine po miladu $)^{4} \mathrm{i}$ odmah je kao mlad počeo tragati za znanjem $\mathrm{i}$ slušanjem hadisa od poznatih učenjaka svoga područja. Čuo je hadise od Abdullaha ibn Avna (koji je umro 151. godine po H.). Nakon toga je krenuo putovati u potrazi za hadisom $\mathrm{i}$ slušanjem hadisa u drugim gradovima, poput Medine, Bagdada, Kufe i tako dalje.

\section{Njegovi učitelji od kojih je slušao hadise:}

$S$ obzirom na to da je Et-Tajalisi živio relativno rano, tj. blizu Poslanikovog, s.a.v.s., vremena, bio je u prilici da čuje hadis od nekih tabi'ina, kao što su Ejmen ibn Nabil, Abdurrahaman ibn Verdan i EbuEjjub ibn Ebi-Salih, te se zbog toga ubraja među tabi'i tabi'ine, koji su učenjaci od prva tri odabrana stoljeća/el-kununul-mufeddale. Spominje se da je čuo hadis od hiljadu učitelja, kao što to kaže sam Et-Tajalisi: Slušao sam hadis od hiljadu učitelja. ${ }^{5}$

Najpoznatiji od njegovih učitelja je - bez ikakvog premca - Šu'be ibn Hadžadž, koji slovi kao jedan od najpoznatijih prenosioca hadisa. Upravo zbog toga Šu'be zaslužuje posebnu titulu u hadiskoj nauci: emirulmu'minine fil-hadis/vladar pravovjernih u hadisu, od kojeg je Et-Tajalisi

\footnotetext{
${ }^{3}$ Es-Sem'ani, El-Ensab, 4/91.

${ }^{4}$ Zerikli, El-E'alam, 3/125.

${ }^{5}$ Halife, Tabekat, str. 227, Idžli, Tertibus-Sikat, str. 201, Ed-Dulabi, El-Kuna, 1/169, El-Mizzi, Tehzibul-kemal, 1/534, Ibn Hadžer, Et-Tehzib, 4/182 itd.
} 
čuo oko sedam hiljada hadisa. To potvrđuje naredna izreka Ahmeda ibn El-Furata, koji kaže: Nisam vidio nikog da je prenio više hadisa od Šu'be kao što je Ebu-Davud et-Tajalisi. Jedan od njegovih učitelja također je Osman el-Burri, za kojeg Et-Tajalisi kaže: U svojim grudima pamtim dvanaest hiljada hadisa koje sam čuo od Osmana el-Burrija. Od njegovih učitelja mogu se još nabrojati i: Hammad ibn Seleme, Hemmam ibn Jahja, Hammad ibn Zejd, Ebu-Avane el-Veddah ibn Abdullah el-Ješkuri, Abdullah ibn Mubarek, Mubarek ibn Fedale, Harb ibn Šeddad, Ibrahim ibn Sead, Isra'il ibn Junus, Zaide ibn Kudame, Verka' ibn Amr elMes'udi, Vuhejb ibn Halid el-Bahili, Er-Rebi' ibn Sabih, Muhammed ibn Abdurrahman ibn Ebi Zi'b, Me'aruf ibn Harrebuz, Talhe ibn Amr, dvojica Sufjana (tj. Sufjan ibn Ujejne i Sufjan es-Sevri), Bistam ibn Muslim, Kurre ibn Halid, Salih ibn Ebi-Ahdar, Džerir ibn Hazim, Fulejh ibn Sulejman, Zuhejr ibn Muavije, Zem'a ibn Salih, Džerir ibn Abdulhamid, Ebu-Ahves Sellam ibn Sulejm i mnogi drugi. ${ }^{6}$

\section{Njegovi učenici koji su prenijeli hadis od njega:}

Najpoznatiji od Et-Tajalisijevih učenika je Junus ibn Habib Ebu-Bišr elAsbehani koji je prenio njegov Musned od njega i Ebu-Mes'ud er-Razi, učenjak koji je sakupio ovaj Musned Junusu ibn Habibu.

Jedan od Et-Tajalisijevih učenika je poznati imam Ahmed ibn Hanbel, autor najpoznatijeg i najraširenijeg Musneda u kojem ima oko 35 hiljada hadisa. Njegovi učenici su i: Ali ibn el-Medini, Muhammed ibn Beššar, zvani Bundar, Mahmud ibn Gajlan, Amr ibn Ali el-Felas, Ja'kub edDevreki, Muhammed ibn Se'ad el-Katib, Abbas ed-Duri, Ahmed ibn Ibrahim ed-Devreki, Ahmed ibn Asim, Harun ibn Sulejman, Bekkar ibn Kutejbe, Ebu-Bekr ibn Ebi Šejbe, Osman ibn Ebi-Šejbe, Suvar ibn Abdullah, Abbas el-Anberi, Zejd ibn Ahrem i drugi. ${ }^{7}$

\footnotetext{
${ }^{6}$ El-Mizzi, Tehzibul-kemal, 1/534, Ibn Hadžer, Et-Tehzib, 4/182.

${ }^{7}$ El-Mizzi, Tehzibul-kemal, 1/534, Ibn Hadžer, Et-Tehzib, 4/182.
} 


\section{Riječi hvale o Et-Tajalisiju:}

Svi učenjaci i hadiski kritičari su složni u tome da se Et-Tajalisi ubraja među najbolje i najpouzdanije hadiske stručnjake. Među najpoznatijim kritičarima i hadiskim autoritetima koji su ga opisali kao pouzdanog i povjerljivog muhaddisa bili su: Ahmed ibn Hanbel, Ibn-Se'ad, Amr ibn Ali, Nesa'i, Idžli, Hatib Bagdadi, Ibn-Hibban i mnogi drugi.

Evo nekih izreka u kojima se govori o njegovom pamćenju kojim ga je Svemogući Allah obdario:

El-Fellas i Ibn el-Medini su rekli: Nisam vidio nikog da bolje pamti hadis od Et-Tajalisija.

Ibn-Mehdi je rekao: On je najiskreniji prenosilac hadisa.

Veki' je rekao: Nije ostao niko da bolje pamti duge hadise od Et-Tajalisija, a drugom prilikom je rekao: Ebu-Davud je brdo/gromada znanja.

Amr ibn Šebbeh je kazao: U Asbehanu su učenici zapisali četrdeset hiljada hadisa koje im je izdiktirao Ebu-Davud Et-Tajalisi napamet.

Ebu-Davud, ne hvaleći se a ističući Allahovu, dž.š., blagodat i moć pamćenja, o sebi kaže: Mogu vam citirati trideset hiljada hadisa, ali to ne kažem da bih se pohvalio, a u svojim grudima pamtim dvanaest hiljada hadisa koje sam čuo od Osmana el-Burrija.

Sulejman ibn Harb kazuje: Šu'be, emirul-mu'minine fil-hadis/vladar pravovjernih u hadisu. bi u svom medžlisu/halki citirao hadise, pa kada bio on ustao, onda bi Ebu-Davud et-Tajalisi sjeo i napamet ponovio sve ono što je $\check{S}_{\text {u'be rekao. }}$

$\mathrm{Na}$ njegove vrline i povjerljivost ukazuje i slijedeći događaj koji prenosi Junus ibn Habib: Došao nam je Ebu-Davud u Asbehan i izdiktirao nam stotinu hiljada hadisa, pa kada se vratio u Basru napisao nam je da je pogriješio na sedamdeset mjesta, pa ih popravite!

Ove velike cifre koje se spominju, kada se govori o broju hadisa, podrazumijevaju različite predaje ponovljenih hadisa, tako da se nekada jedan hadis može brojati po desetak puta $u$ različitim verzijama i varijantama, pa to hadiski učenjaci broje kao poseban hadis. 
Svi ljudi ponekad pogriješe, pa bi tako i Ebu-Davud u mnoštvu onoga što je napamet citirao ponekad pogriješio, ali se to, u odnosu na mnoštvo hadisa koje prenosi, smatra beznačajnim.

Hatib Bagdadi je rekao: Ebu-Davud je mnogo hadisa citirao napamet, a pamćenje nekada prevari čovjeka, pa bi i on nekada pogriješio, ali te njegove greške su beznačajne u usporedbi sa mnoštvom onoga što je ispravno i tačno prenio.

Uz sve ovo što je spomenuto, Ebu-Davud et-Tajalisi smatra se jednim od pouzdanih i povjerljivih stručnjaka i hafiza u hadiskoj oblasti. Također se ubraja i među kritičare koji su bili sposobni da ocjenjuju hadiske predaje, kao i same prenosioce hadisa. Kao takvog su ga opisali Zehebi, Sehavi i drugi hadiski autoriteti, ne uvrštavajući ga ni među stroge, niti među previše blage kritičare hadskih predaja. ${ }^{8}$

\section{Njegova smrt:}

Ebu-Davud et-Tajalisi, rahimehullah, umro je u Basri u mjesecu saferu, 204. godine po H. Tada je imao sedamdeset i dvije godine.

Muhammed ibn Beššar je rekao: 'Nisam ni za kim plakao kao što sam plakao za Ebu-Davudom kada je umro.' Prisutni ga upitaše: 'A zašto to', a on reče: 'Zbog njegovog izuzetnog pamćenja, poznavanja i lijepog ophodenja prilikom preslušavanja hadisa.' Neka se Allah smiluje i njima i nama. ${ }^{9}$

\section{Musned Ebu-Davuda et-Tajalisija}

Ovdje ćemo govoriti o Musnedu Ebu-Davuda et-Tajalisija i to sa više aspekata.

\footnotetext{
${ }^{8}$ Halife, Tabekat, str. 227, Idžli, Tertibus-Sikat, str. 201, Ed-Dulabi, El-Kuna, 1/169, El-Mizzi, Tehzibul-kemal, 1/534, Ibn Hadžer, Et-Tehzib, 4/182 i ostale knjige o prenosiocima hadisa.

${ }^{9}$ Halife, Tabekat, str. 227, Idžli, Tertibus-Sikat, str. 201, Ed-Dulabi, El-Kuna, 1/169, El-Mizzi, Tehzibul-kemal, 1/534, Ibn Hadžer, Et-Tehzib, 4/182, Zerikli, El-E'alam, $3 / 125$.
} 


\section{Tačan naziv njegove knjige i vjerodostojnost njegovog autorstva iste}

Naziv njegove knjige je Musned, kao što je već spomenuto, a to potvrđuje slijedeće:

- njegov način i stil bilježenja hadisa, a to je uobičajeni stil hadiskih zbirki koje nose identičan naziv,

- svi učenjaci koji su pisali biografiju Ebu-Davuda et-Tajalisija, između ostalog rekli su za njega da je autor Musneda,

- njegov Musned se navodi u hadiskim knjigama kao primjer za vrstu hadiskih zbirki koje nose taj naziv.

Što se tiče autentičnosti i vjerodostojnosti pripisivanja ove knjige EbuDavudu, to je jasna činjenica zbog slijedećih razloga:

- postojanje seneda/lanca prenosioca na početku rukopisa ovog djela koji seže sve do Ebu-Davuda et-Tajalisija, a to je potpuno spojen sened pouzdanih i povjerljivih prenosioca hadisa,

- jasna izjava Junusa ibn Habiba - prenosioca ovog Musneda - da je on lično čuo sve hadise ovog Musneda direktno od Et-Tajalisija i ta izjava se nalazi na početku svakog dijela ove knjige,

- spominjanje mnogobrojnih pouzdanih izjava o slušanju i prenošenju ovog Musneda na kraju svakog dijela,

- autori poznatih hadiskih zbirki ponekad bilježe hadise ovog Musneda u svojim hadiskim zbirkama, preko Junusa ibn Habiba, od Ebu-Davuda etTajalisija, potpuno identično kao što su navedeni u ovom Musnedu, poput imama Bejhekija, Ebu-Nuajma i drugih. Kao primjer može se navesti ovaj hadis iz Musneda:

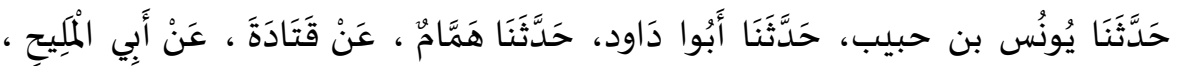

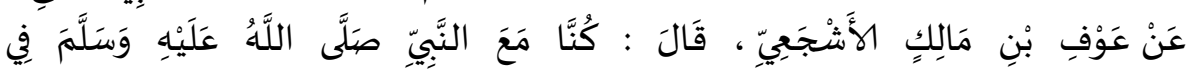
سَفَرِ...الحديث عَّيث

Kao što se vidi, Junus ibn Habib (prenosilac/ravija ovog Musneda) kaže: Pričao nam je Ebu-Davud (Et-Tajalisi), koji kaže: 'Pričao nam je 
Hemmam, od Katade, od Ebul-Meliha, a on od Avfa ibn Malika elEšdže'ija, koji je ispričao: "Bili smo sa Vjerovjesnikom, s.a.v.s., na putu..." pa je spomenuo hadis o šefa'atu. ${ }^{10}$

Ovaj isti hadis je zabilježio Bejheki u svojoj knjizi Delailun-nubuvveh, 7/87 spomenuvši ovaj sened:

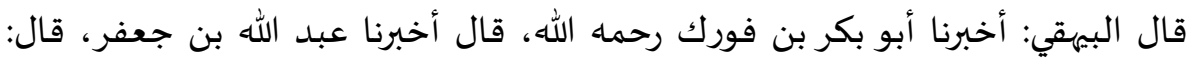

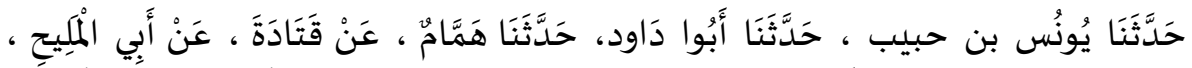

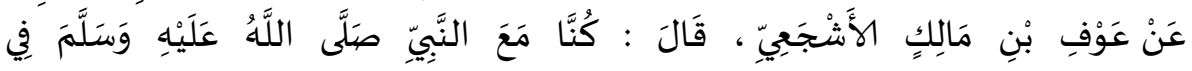

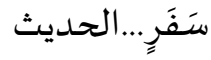

Bejheki je zabilježio: Obavijestio nas je Ebu-Bekr ibn Furek, rahimehullah, koji kaže: 'Obavijestio nas je Abdullah ibn Dže'afer, koji kaže: „Obavijestio nas je Junus ibn Habib, koji kaže: „Pričao nam je EbuDavud (Et-Tajalisi), koji kaže: "Pričao nam je Hemmam, od Katade, od Ebul-Meliha, a on od Avfa ibn Malika El-Ešdže'ija, koji je ispričao: "Bili smo sa Vjerovjesnikom, s. a. v. s., na putu..."', pa je spomenuo hadis o šefa'atu. Vidimo da je Bejheki naveo potpuno isti sened (u kojem je EbuDavud et-Tajalisi) $i$ isti hadis.

\section{Rukopisi ovog djela}

Ovo djelo ima nekoliko rukopisa, od kojih su najpoznatija tri, a to su: rukopis koji je sačuvani u vakufskoj biblioteci u Bagdadu, rukopis koji se čuva u biblioteci Hadabahš u gradu Betne u Indiji i rukopis sačuvan u lasifijskoj biblioteci u Hajderabadu u Indiji.

U prodaji se nalazi štampan Musned Ebu-Davuda et-Tajalisija u jednom tomu, velikog formata. To je prva štampana varijanta ovog Musneda. Štampan je u Indiji u Hajderabadu 1321. godine po H., na 362 stranice, plus razlike u rukopisima i sadržaj, tako da kompletan tom sadrži više od 400 stranica. Broj hadisa koji su tu spomenuti je 2767. To je ustvari sve što je sačuvano od njegovog Musneda. Kaže se da je tu bilo oko 30 hiljada hadisa.

${ }^{10}$ Ebu-Davud et-Tajalisi, Musned, str. 134. broj hadisa: 998. 


\section{Savremena izučavanja ovog Musneda}

S obzirom da Ebu-Davud et-Tajalisi u svom Musnedu nije ocijenio vjerodostojnost spomenutih hadisa, kao što su to radili neki drugi autori hadiskih zbirki, poput Tirmizije, ukazala se potreba studioznijeg proučavanja i valorizacije hadisa njegovog Musneda. Na osnovu te potrebe Islamski univerzitet Muhammed b. Sand u Rijadu, Saudijska Arabija, na fakultetu Usulid-din, odsjek Hadis i njegove znanosti, je devedesetih godina (tačnije 1991 - 1992. godine) što odgovara 1411. godine po H., pokrenuo projekt prijave magistarskih teza na tom polju. Desetak studenata postdiplomskog studija, nakon što su završili četiri semestra postdiplomskog studija, prijavilo je ovu temu i svakom od njih je dodijeljen određeni broj hadisa. Njihova zadaća je bila da na osnovu spomenutih rukopisa detaljno obrade i prepišu tekst hadisa EtTajalisijevog Musneda, zatim da stručno prouče senede svakog hadisa, da urade tahridž/spominjanje ostalih hadiskih zbirki u kojima se ti hadisi nalaze, te da na kraju donesu ocjenu svakog hadisa pojedinačno. Prvi od tih studenata bio je Muhammed et-Turki iz Saudijske Arabije, a jedan od ostalih desetak studenata bio je i potpisnik ovih redova. Odbrana ove magistarske teme bila je 1991. godine na spomenutom fakultetu. Detaljna obrada 302 hadisa koje je obrađivao zauzeli su više od 900 stranica (plus razni indeksi i fehresi) kucanog teksta, A4 formata, na arapskom jeziku.

\section{Stil Et-Tajalisija $\mathrm{i}$ njegov način bilježenja hadisa $u$ ovom Musnedu}

Et-Tajalisi je hadise u svom Musnedu poredao onako kako to uobičajeno rade autori hadiskih zbirki ovog tipa, poput imama Ahmeda ibn Hanbela, El-Humejdija i drugih muhaddisa. To se ogleda u slijedećem načinu:

- ako određeni ashab, čije hadise bilježi, bude od onih koji su prenijeli mali broj hadisa od Poslanika, s. a. v. s., on ih spominje bez određenog redoslijeda. Da bi se to bolje razumjelo, može se pogledati prvih šezdeset i pet hadisa (u dijelu koje sam ja obrađivao). Sve njih prenosi dvanaest ashaba, pa to izgleda otprilike ovako: Avf ibn Malik (prenosi 2 hadisa), 
Ukbe ibn Amir (11), Fedale ibn Ubejd (1), Vasile ibn Eska' (2), EbuSe'alebete el-Hušeni (3) i tako dalje;

- kada neki ashab bude od onih koji prenose veliki broj hadisa od Poslanika, s. a. v. s., onda autor te hadise raspoređuje prema tabi'inima koji te hadise prenose od dotičnog ashaba. Primjer za to je Enes ibn Malik, r. a., koji od Vjerovjesnika, s. a. v. s., prenosi u ovom dijelu musneda 192 hadisa. Et-Tajalisi je ove hadise poredao prema tabi'inima koji hadise prenose od Enesa, r. a., pa je počeo sa hadisima koje od Enesa, r. a., prenosi Katade, zatim tabi'in Sabit el-Bunani, zatim hadisi Alija ibn Zejda ibn Džud'ana i tako sve dok ne kaže: Pojedinci koji su prenijeli hadise od Enesa, $r$. a.

\section{Njegov način bilježenja seneda/lanca hadisa}

Et-Tajalisi senede spominje na uobičajen način, spominjući prvo jedan sened, od početka do kraja, a zatim spominje metn/tekst samog hadisa. Ipak se ponekad dešava da on odstupi od ove uobičajene prakse pa primijeni neku drugu metodu, kao npr.:

- da spomene dvojicu ili trojicu svojih učitelja od kojih je slušao taj hadis, zatim spominje ostatak seneda od njih pa dalje. Kao primjer navest ćemo slijedeće:

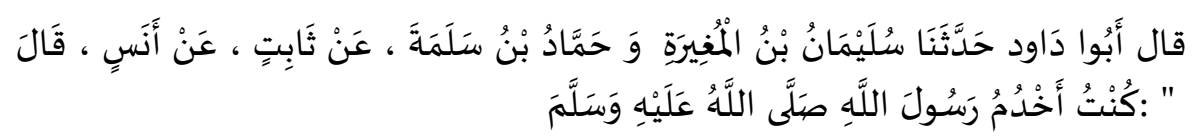

Ebu-Davud et-Tajalisi kaže: Pričali su nam Sulejman ibn Mugire $i$ Hammad ibn Seleme od Sabita, od Enesa, r. a., koji kaže: „Služio sam Poslanika, s. a. v. s.,... ${ }^{11}$ Ovdje su Sulejman i Hammad Ebu-Davudovi učitelji.

- ako postoji razlika u načinu preuzimanja hadisa, ili nešto drugo kod tih njegovih učitelja, on na to upozori, kao što je ovaj primjer:

${ }^{11}$ Ebu-Davud et-Tajalisi, Musned, str. 271. broj hadisa: 2032. 


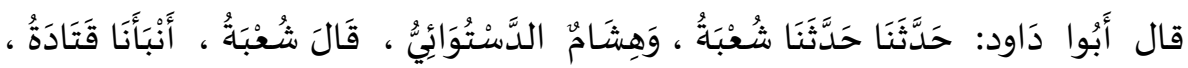

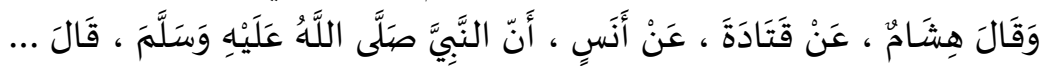

U ovom hadisu Ebu-Davud kaže: Pričali su nam Šu'be i Hišam edDesteva'i. Šu'be je rekao: 'Pričao nam je Katade', a Hišam je rekao: 'Od Katade, od Enesa, da je Vjerovjesnik, s. a. v. s., rekao...' ${ }^{12}$

- također, Et-Tajalisi upozorava na razliku u metnu/tekstu hadisa ako se ona nađe, kao npr.:

$$
\text { ...قال أَبُوا دَاود: قَالَ هِشَامُ : ذَرَّةً ، وَقَالَ شُعْبََة : ذُرَةً }
$$

Ebu-Davud, nakon citiranja seneda i hadisa, kaže: Hišam je u svojoj predaji rekao: zerreh (sa tešdidom), a Šu'be je rekao: zureh (bez tešdida).

- ponekad spomene dvojicu ravija/prenosilaca hadisa iz neke druge generacije, mimo svojih učitelja i tome slično;

- ponekad spomene dvojicu ashaba, jednog čije hadise tu spominje, ali s njim spominje i nekog drugog ashaba. Kao primjer može poslužiti ovo:

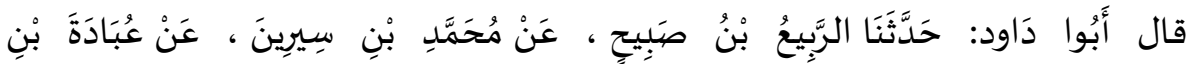

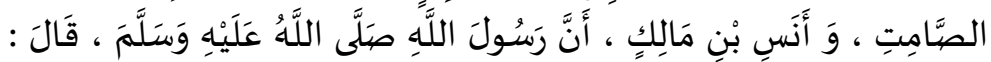

Ebu-Davud et-Tajalisi kaže: Pričao nam je Rebi' ibn Sabih, od Muhammeda ibn Sirina, od Ubeda ibn Samita i Enesa ibn Malika, r. a., da je Poslanik, s. a. v. s., rekao... ${ }^{13}$ Ovdje vidimo da je u sklopu Enesovih, r. a., hadisa uz njega spomenuo i drugog ashaba Ubadu ibn Samita, r. a.

- nekada u sklopu hadisa od jednog ashaba, spomene drugi sened od drugog ashaba, koji također prenosi taj hadis. Kao npr.:

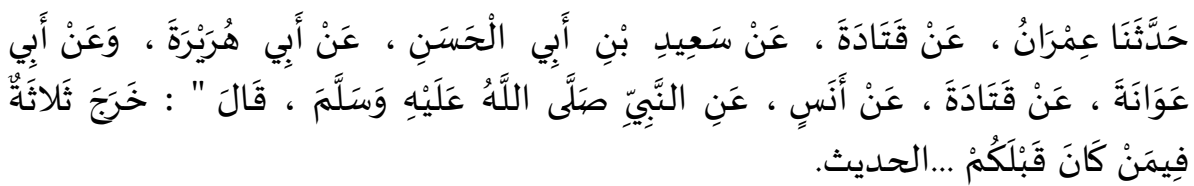

\footnotetext{
${ }^{12}$ Ebu-Davud et-Tajalisi, Musned, str. 265. broj hadisa: 1961.

${ }^{13}$ Ebu-Davud et-Tajalisi, Musned, str. 285. broj hadisa: 2143.
} 
Ebu-Davud kaže: 'Prǐ̌ao nam je Imran, od Katade od Seid ibn EbilHasena od Ebu-Hurejre, r. a. A od Ebu-Avane, od Katade od Enesa, r. a., od Vjerovjesnika, s. a. v. s., da je rekao: "Od naroda koji su živjeli prije vas trojica ljudi su izašli... " ${ }^{14}$, pa je spomenuo hadis. U ovom slučaju vidimo da je Et-Tajalisi u sklopu Enesovih, r. a., hadisa spomenuo sened od još jednog ashaba, tj. Ebu-Hurejre, r. a.

- ponekad Ebu-Davud ponavlja isti sened za više hadisa koji dolaze jedan za drugim. To je posebno došlo do izražaja kod prenošenja Šu'be od Katade od Enesa, r. a., ili kod prenošenja Hammada ibn Seleme od Sabita el-Bunanija od Enesa, r. a., ili prenošenje Rebi'a ibn Sabiha od Jezida er-Rekašija i tome slično;

- ponekad za jedan metn/tekst hadisa spominje više seneda/lanaca prenosilaca, pa se nekada i ti metnovi razlikuju, neki su duži a neki kraći;

- ponekad za jedan metn/tekst hadisa spominje dva seneda/lanca prenosilaca od kojih je jedan kraći a drugi duži.

Ebu-Davudov način spominjanja njegovih učitelja je da se uglavnom zadovoljava sa njihovim prvim imenima, njihovim nadimcima, ili onim po čemu su najpoznatiji, kao što su: Šu'be, Hušejm, Hišam, Ebu-Avane, El-Mes'udi i tome slično.

Ponekada se spominje mubhem/neimenovana osoba u senedu hadisa i to uglavnom kod prenosilaca mimo njegovih učitelja.

Nekada i sam Ebu-Davud govori o vjerodostojnosti pojedinih prenosilaca. Evo primjera za to:

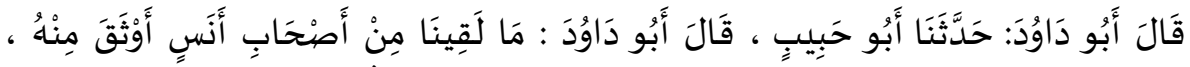

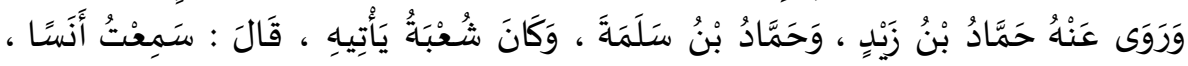

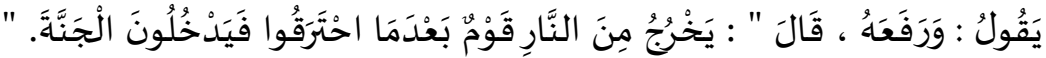

Ebu-Davud kaže: 'Pričao nam je Ebu-Habib.' Zatim kaže: 'Nismo sreli od Enesovih učenika povjerljivijeg od njega, od njega su hadise prenosili Hammad ibn Zejd i Hammad ibn Seleme, a i Šu'be je kod njega dolazio',

${ }^{14}$ Ebu-Davud et-Tajalisi, Musned, str. 269. broj hadisa: 2014. 
on kaže: 'Čuo sam Enesa kako prenosi da je Poslanik, s.a v.s., rekao: "Iz Džehennema će izići ljudi nakon što su izgorjeli u vatri, pa će ući u Džennet."' 15

\section{Njegov način bilježenja metna/teksta hadisa}

Ebu-Davud uglavnom spominje kompletan metn/tekst hadisa, nakon što spomene sened/lanac prenosilaca tog hadisa.

Nekada, umjesto navođenja metna, upućuje na metn koji je prethodio tom, govoreći: slično prethodnom hadisu.

Mnogo puta se dešava da ponovi isti metn/tekst hadis na nekoliko mjesta sa različitim senedom, a nekada i sa razlikom u metnu, nekad duži, nekad kraći.

Ponekad duži hadis podijeli u više cjelina, pa kod svake do njih spominje njegov sened, a nekada spomene preostatak hadisa bez kompletnog senedal mullekan.

Rjeđe se dešava da spomene više metnova sa istim sendom.

Nekada Ebu-Davud lično pojašnjava nepoznatu arapsku riječ, koja je spomenuta u hadisu, kao npr.:

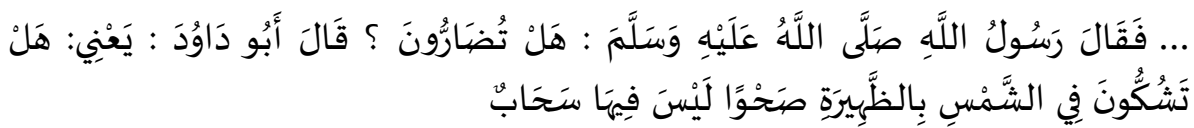

Allahov Poslanik, s.a.v.s., je rekao: Hel tudarrune, Ebu-Davud kaže: znači: Hel tešukkunelDa li sumnjate u sunce koje u podne jasno vidite, kad nema oblaka ${ }^{16}$, ili se desi da Ebu-Davud prenosi nečije pojašnjenje neke nepoznate riječi u hadisu.

\section{Njegovi učitelji u djelu Musneda}

Već smo rekli da je Ebu-Davudov najpoznatiji učitelj Šu'be ibn Hadžadž emirul-mu'minine fil-hadis/vladar pravovjernih u hadisu i od njega je

\footnotetext{
15 Ebu Davud Et-Tajalisi, Musned, str. 284. broj hadisa: 2137.

${ }^{16}$ Ebu Davud Et-Tajalisi, Musned, str. 289. broj hadisa: 2179.
} 
prenio daleko najviše hadisa. U ovom djelu je trećinu hadisa prenio od Šu'be, a od ostalih svojih učitelja manje hadisa. Od 34 učitelja prenio samo po jedan hadis.

\section{Posebne vrijednosti ovog Musneda}

Jedna od najvažnijih odlika ovog Musneda je da su u njemu spomenuti hadisi kojih nema zabilježenih u šest najpoznatijih hadiskih zbirki/kutubu sitte. Od ovih trista hadisa koji su obrađivani u Musnedu nalaze se 24 takva hadisa. Od ova 24 hadisa, njih pet je zabilježio Et-Tajalisi u svome Musnedu.

Kratkoća Et-Tajalisijevih seneda/lanaca je također jedna od odlika Musneda, tako da su skoro dvije trećine njegovih hadisa od tzv. sulasijjata, tj. da između njega i Vjerovjesnika, s.a.v.s., imaju samo tri prenosioca. Razlog postojanja ovolikog broja sulasijjata je zato što je EbuDavud živio relativno blizu prvih generacija (umro je 204. po H.), a također i ashab Enes ibn Malik, r.a., od kojeg bilježi hadise u ovom djelu, koji je živio sve do 93. po H.

Čak imaju dva seneda u kojima između Ebu-Davuda i Vjerovjesnika, s.a.v.s., imaju samo dva prenosioca. To izgleda ovako:

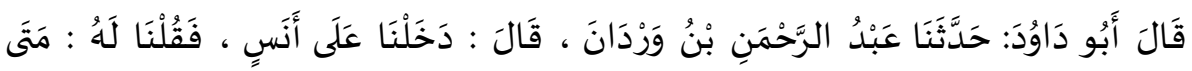

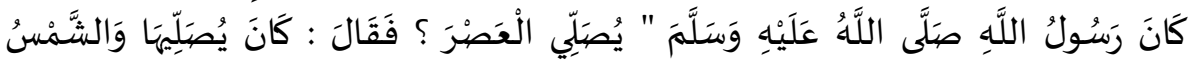

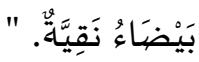

Ebu-Davud kaže: Pričao nam je Abdurrahman ibn Verdan koji kaže: 'Ušli smo kod Enesa i upitali ga: "Kad je Vjerovjesnik, s.a.v.s., klanjao ikindiju namaz?" On reče: „Klanjao je dok je sunce još bili bijelo-čisto. " 17

\section{Hadisi koji se nalaze samo u Musnedu Ebu-Davuda et-Tajalisija}

Već smo spomenuli da ima jedan broj hadisa koje je zabilježio samo EbuDavud et-Tajalisi u svome Musnedu i nema ih u drugim poznatim,

${ }^{17}$ Ebu Davud Et-Tajalisi, Musned, str. 284. broj hadisa: 2138. 
temeljnim i dostupnim hadiskim zbirkama. Riječ je o slijedećim hadisima:

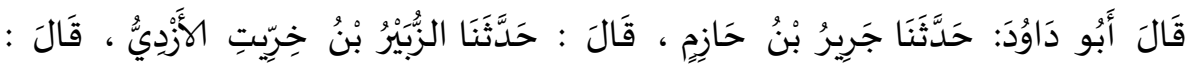

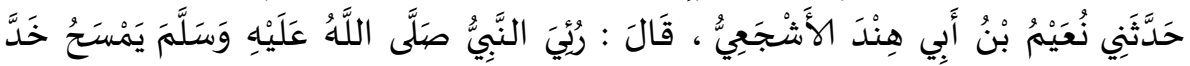

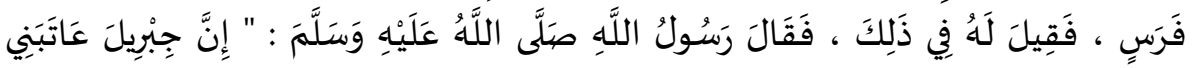

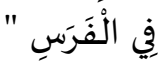

Ebu-Davud je zabilježio: Pričao nam je Džerir ibn Hazim koji kaže da im je pričao Zubejr ibn Hirrit el-Ezdi koji kaže: 'Pričao mi je Nuajm ibn Ebi Hind el-Ešdže'i koji kaže: "Viđen je Vjerovjesnik, s.a.v.s., kako gladi konja po obrazu. Kada je upitan o tome, on reče: "Zaista me Džibril, a.s., ukorio zbog konja."'18

Nakon toga, prenosilac Et-Tajalisijevog Musneda Junus ibn Habib (EbuBišr) spominje drugi sened u kojem se spominje ashab Urve ibn Dže'ad, koji nije spomenut u prethodnom senedu pa kaže:

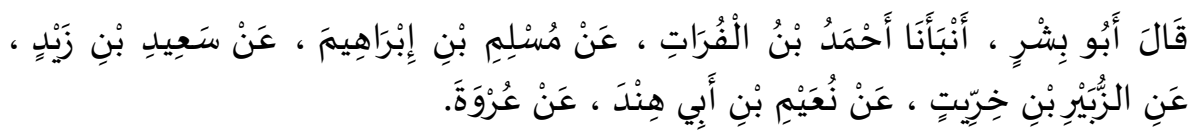

Pričao nam je Ahmed ibn el-Furat od Muslima ibn Ibrahima, od Seida ibn Zejda, od Zubejra ibn Hirrita od Nuajma ibn Ebi-Hinda, od Urve...

Ovaj hadis se ne nalazi ni u jednoj od temeljnih hadiskih zbirki, samo ga je po značenju spomenuo hafiz Ibn-Hadžer u svojoj knjizi El-Metalibulalije, 2/158 (1928) pripisujući ga samo Et-Tajalisiju u njegovom Musnedu. Slično značenje ovog hadisa je zabilježio Taberani u svom Velikom Mu'džemu, 17/158 (414), gdje Urve ibn Dže'ad, r. a., kaže: Vidio sam Vjerovjesnika, s.a.v.s., kako plete grivu svoga konja svojim prstima a zatim reče: 'U konjskim grivama se nalazi dobro.' $\mathrm{Na}$ osnovu spomenuta dva seneda i predaje koja se nalazi kod Taberanija, kao i šahida/hadisa od drugog ashaba koji potvrđuje njegovu ispravnost (to je hadis od Džerira ibn Abdullah koji je zabilježio Muslim, 13/20 (4824),

${ }^{18}$ Ebu Davud Et-Tajalisi, Musned, str. 142. broj hadisa: 1059. 
može se reći da ovaj hadis dostiže stepen sahih li gajrihi/pouzdan zbog drugih hadisa.

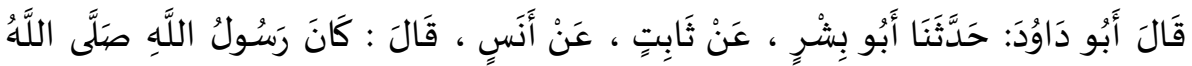

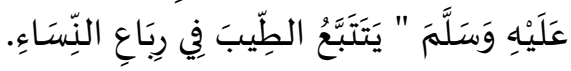

Ebu-Davud je zabilježio: Pričao nam je Ebu-Bišr, od Sabita, od Enesa, r. a., koji kaže: 'Allahov Poslanik, s.a.v.s., bi potraživao miris u kućama svojih supruga.'

Ovo je sahih hadis i pored Et-Tajalisijevog Musneda zabilježio ga je EsSem'ani u svojoj knjizi Edubul-imla' vel-istimla', str. 32. Također ga je spomenuo Eš-Šejh el-Hindi u Kunzul-ummalu, 7/123 (18293), pripisujući ga Et-Tajalisiju u njegovom Musnedu.

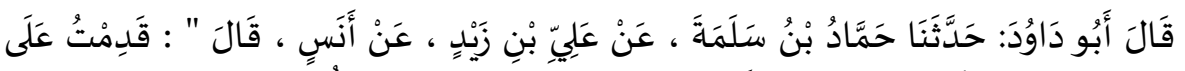

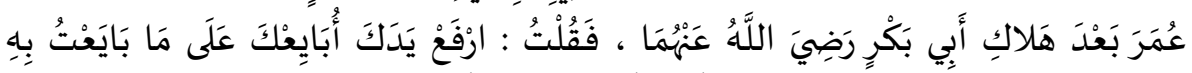

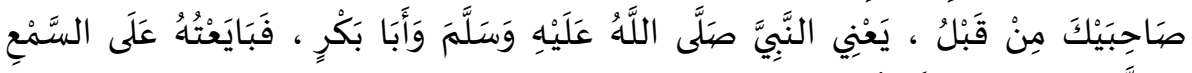

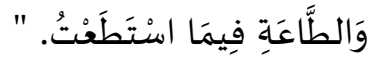

Ebu-Davud je zabilježio: Pričao nam je Hammad ibn Seleme, od Ali ibn Zejda, od Enesa, r. a., koji kaže: 'Došao sam kod Omera, r. a., nakon EbuBekrove, r. a., smrti pa sam mu rekao: Daj mi ruku da ti dam bej'at/prisegu kao sto sam je ranije dao dvojici tvojih omiljenih prijatelja (misli na Vjerovjesnika, s.a.v.s., i Ebu Bekra, r.a.), pa sam mu dao bej'atlobavezao se na poslušnost i pokornost u svemu što sam u stanju učiniti.'

Ovaj hadis je hasen li gajrihi/dobar zbog drugih hadisa koji ga ojačavaju. Ne nalazi se u drugim temeljnim hadiskim zbirkama, ali je sličnu predaju spomenuo hafiz El-Busiri u Muhtesarul-ithaf, 2/76 pripisujući ga EtTajalisiju. Po značenju ga je spomenuo hafiz Ibn-Hadžer u svojoj knjizi El-Metalibul-alije, 2/207 (2058), pripisujući ga samo Et-Tajalisiju u njegovom Musnedu.

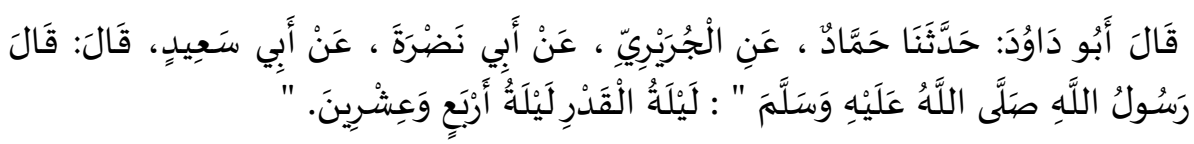

Ebu-Davud je zabilježio: Pričao nam je Hammad, od El-Džurejrija, od Ebi-Nadrete, od Ebu-Seida, r. a., (El-Hudrija) da je Allahov Poslanik, 
s.a.v.s., rekao: 'Noć kadra/Lejletul-kadr je dvadeset i četvrta noć Ramazana.' Opće je poznato da najviše predaja ukazuje da je ona dvadeset i sedme noći Ramazana. Iz ove predaje bi se moglo protumačiti da je riječ o sedmoj, neparnoj noć od kraja Ramazana, brojeći unazad.

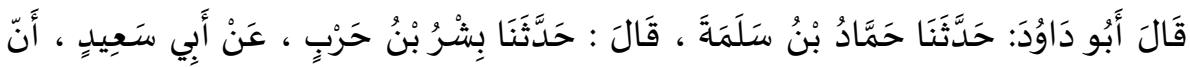

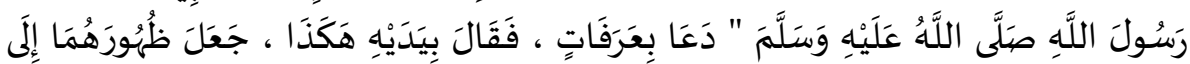

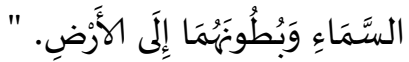

Ebu-Davud je zabilježio: Pričao nam je Hammad ibn Seleme, koji kaže da im je pričao Bišr ibn Harb, od Ebu-Seida, r.a.,(El-Hudrija) koji kaže: 'Allahov Poslanik, s.a.v.s., je na Arefatu učio dovu, pa je rukama ovako učinio, okrenuvši dlanove prema zemlji, a vanjsku stranu prema nebu.'

Ovaj hadis je slab zbog toga što se u njegovom lancu nalazi Bišr ibn Harb, a to je iskren prenosilac kod kojeg se nađe slabost.

Ovaj hadis se ne nalazi u drugim temeljnim hadiskim zbirkama, ali ga je po značenju spomenuo hafiz Ibn-Hadžer u svojoj knjizi El-Metalibulalije, 1/345 (1166), kao što ga spomenuo hafiz El-Busiri u Muhtesarulithaf, 1/161, pripisujući ga Ahmedu ibn Meni'u i smatrajući ga slabim hadisom. Također ga je spomenuo Eš-Šejh el-Hindi u Kunzul-ummalu, 5/187 (12553), pripisujući ga Ibn Ebi-Šejbi, iako ga u njegovom Musannefu nisam pronašao.

\section{Vjerodostojnost hadisa Et-Tajalisijevog Musneda}

Jedna od vrlina ovog Musneda je također da je većina hadisa u njemu od onih hadisa koji se uzimaju kao argument. U ovom djelu u kojem su 302 hadisa, situacija je slijedeća:

Tu su 53 mutevatir hadisa, 199 sahih hadisa, od kojih su 128 muttefekun alejhi, od kojih je jedan mensuh/derogiran. Ima 26 hasen hadisa, od kojih je 25 dostiglo stepen sahih li gajrihilsahih zbog drugih hadisa koji su ga ojačali. Daif hadisa ima 77, od kojih je 49 dostiglo stepen sahih li gajrihilsahih zbog drugih hadisa koji su ga ojačali, a 13 je dostiglo stepen hasen li gajrihilhasen zbog drugih hadisa koji su ga ojačali. Preostalo je još 13 hadisa slabog seneda i dva hadisa vrlo slabog senedalšedidud-d'afi. 
Osim toga, vrlina ovog Musneda je također u tome da se u njemu nalaze vrlo važne napomene oko značenja nekih hadisa, pojašnjenja vjerodostojnosti prenosioca, jasno izražavanje da je određeni prenosilac lično čuo hadis od onoga prije njega, ili pojašnjenja je li neki hadis merfu'/Poslanikova, s.a.v.s., izreka ili je mevkuflizreka nekog od ashaba, r.a.

\section{Neke primjedbe na ovaj Musned}

Uz sve ono što je pozitivno izrečeno o ovoj hadiskoj zbirci i uz iskreno uvažavanje, kako njenog autora hafiza Ebu-Davuda et-Tajalisija, tako i samog Musneda, zapažaju se beznačajne greške, kojima su podložni svi ljudi, osim Allahovih, dž. š., poslanika, a. s. Nakon detaljnog i preciznog izučavanja svakog ravije pojedinačno, zatim svakog seneda i hadisa, možemo zapaziti neke nedostatke koji nimalo ne umanjuju vrijednost ovog hadiskog djela. Bitno je napomenuti da su ove greške nekada od strane samog autora Et-Tajalisija, nekada od nekog od njegovih učitelja, ili su to greške koje nastanu prilikom prepisivanja rukopisa i tome slično. Od tih nedostataka su:

- nespominjanje imena pojedinih prenosioca/ibhamur-ravi, što onemogućava donošenje konačne ocjene tog hadisa, zbog nepoznavanja na koga se mislilo od prenosioca, jer da su imena tih prenosioca spomenuta, ta poteškoća bi bila otklonjena;

- nije spomenut ashab u senedu broj 142, a to je Enes ibn Malik, r. a.; ${ }^{19}$

- greška kod imena ashaba u hadisu broj 3, u bagdadskom rukopisu piše: Ukbe ibn Abbas, a ispravno je Ukbe ibn Amir, a djed mu je Abs, (tj. Ukbe ibn Amr ibn Abs), pa je izgleda ovo greška kod prepisivanja rukopisa;

- u hadisu broj 151 u rukopisu stoji: moj amiď̌a, a ispravno je: moj daidža, ali ova greška nije problematična s obzirom da je spomenuto ime tog daidže pa se zna na koga se misli;

${ }^{19}$ Ebu-Davud et-Tajalisi, Musned, str. 271. broj hadisa: 2035. 
- u hadisu broj 93 stoji: da je neka žena od židova, a ispravno je: da je neki čovjek od židova;

- u hadisu broj 75 gdje se opisuje način klanja kurbana stoji: naslonivši njegovu stranu na svoju nogu, a ispravno je: naslonivši svoju nogu na njegovu stranu; ${ }^{20}$

- hadis broj 42 nije pripisan Vjerovjesniku/merfu', mada on ustvari jeste takav; ${ }^{21}$

- prekid u senedu hadisa/inkita', broj 12 i 178;

- pobrkanost/idtirab u senedu hadisa od strane Ebu-Davudovog učitelja (Džerir ibn Hazima) u hadisu broj 135;

- jezičko-gramatička greška u pitanju imena Enes u nominativu/Enesun, a ispravno je da bude u akuzativu/Enesen; pogledaj npr. brojeve hadisa: 66, 87, 88, 90.

Sve ove greške nimalo ne umanjuju vrijednost ove hadiske zbirke. Molimo Allaha, dž. š., da oprosti grijehe njenom autoru, prenosiocima, prepisivačima i svima onima koji su na bilo koji način učestvovali i dalje rade na očuvanju Poslanikovog, s. a. v. s., sunneta.

\section{Zaključak}

Ebu-Davud et-Tajalisi je poznati učenjak i hafiz hadisa, a njegov Musned se ubraja među prve hadiske zbirke koje su nastale. Čak se u Kešfuzzununu kaže da je to prvi musned koji je napisan. Inače su musnedi, hadiske zbirke, u kojima su autori zabilježene hadise razvrstali po ashabima koji dotične hadise prenose od Vjerovjesnika, s. a. v. s., a ashabe, r. a., bi obično redali po njihovim prednostima i zaslugama koje su učinili tokom svog života. Uobičajeni redoslijed ashaba u mesnedima je da se počne sa desetoricom ashaba kojima je obećan Džennet, zatim slijede učesnici bitke na Bedru, pa ashabi koji su prisustvovali ugovoru na Hudejbiji i tome slično.

\footnotetext{
${ }^{20}$ Ebu Davud Et-Tajalisi, Musned, str. 265. broj hadisa: 1968.

${ }^{21}$ Ebu Davud Et-Tajalisi, Musned, str. 139. broj hadisa: 1038.
} 
Musned Ebu-Davuda et-Tajalisija je imao oko 30 hiljada hadisa, mada je od toga sačuvano, nažalost, samo nešto manje od tri hiljade, kako je to nađeno u rukopisima te knjige. Knjiga se odlikuje vjerodostojnošću većine hadisa, na što je utjecalo i to da je Et-Tajalisi među hadiskim učenjacima koji su živjeli u drugom hidžretskom stoljeću, (umro je 204. god. po H.), pa je bio u velikoj prednosti u odnosu na muhaddise koji su došli poslije njega. To je jedna i od karakteristika njegovih kratkih senedaluluvvul-isnad, koja je poželjna kod učenjaka hadisa. Et-Tajalisi se ubraja među tabi'i tabi'ine s obzirom se sreo sa nekoliko tabi'ina i od njih prenio hadise.

S obzirom da Ebu-Davud et-Tajalisi u svom Musnedu nije ocijenio vjerodostojnost spomenutih hadisa, u sklopu hizmeta Poslanikovom, s. a. v. s., sunnetu, Islamski univerzitet Muhammed b. Saud u Rijadu, Saudijska Arabija, na fakultetu Usulid-din, odsjek Hadis i njegove znanosti, je devedesetih godina (tačnije 1991 - 1992. godine) što odgovara 1411. godine po $\mathrm{H}$., pokrenuo projekt stručne obrade i valorizacije rukopisa ovog vrijednog hadiskog djela. Među desetak magistranata iz hadiskih znanosti bio je i potpisnik ovih redova, tako da je kompletan rukopis Musned Ebu-Davuda et-Tajalisija obrađen, proučen sa stručno ocijenjenim senedima, uz mentorstvo najvećih eksperata iz ove oblasti.

\section{Literatura na bosanskome jeziku}

1. - Kur'an s prevodom, preveo Besim Korkut, Medina, 1412. god. po H.

2. - Buhari, Sahihul-Bahari - Buharijeva zbirka hadisa, prvo cjelovito izdanje, VSK, Sarajevo, 2008. g.

3. - Muhammed Nesib er-Rifa'i, Tefsir Ibn-Kesir, skraćeno izdanje, prijevod na bosanski - grupa prevodilaca, Visoki Saudijski komitet za pomoć BiH, Sarajevo, 2000. (1420. god. po H.)

4. - En-Nevevi, Rijadus-salihin, prijevod grupe prevodilaca na bosanski jezik, bez godine izdanja.

5. - Teufik Muftić, Arapsko-bosanski rječnik, Udruženje Ilmije u BiH, Sarajevo, 1973. 


\section{Literatura na arapskome jeziku}

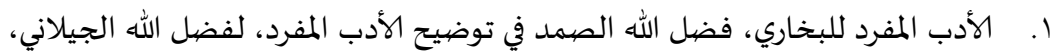

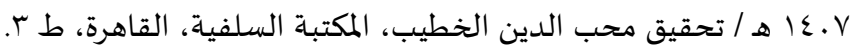

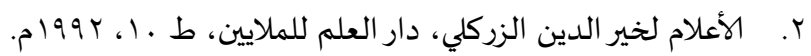

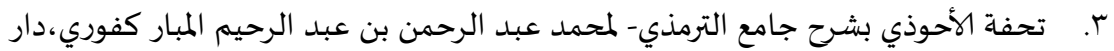
الفكر.

ع. الترغيب والترهيب، لعبد العظيم بن عبد القوي المنذري بتحقيق مصطفى محمد عمارة،

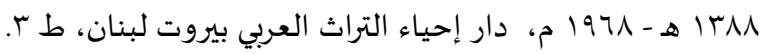

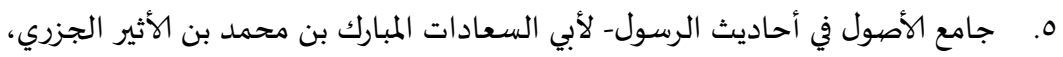

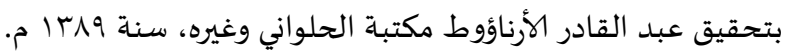

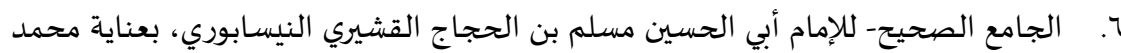

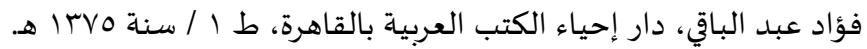

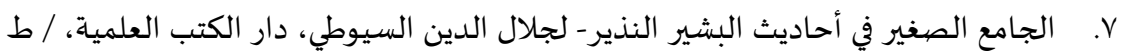

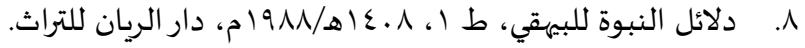

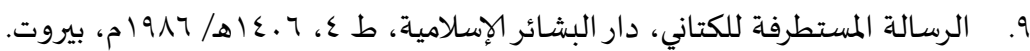

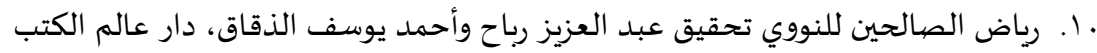

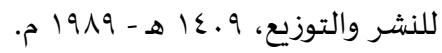

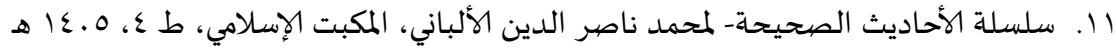
م 1910-

Tr. سلسلة الأحاديث الضعيفة- لمحمد ناصر الدين الألباني، المكتب الإسلامي، ط 0، 0 . أ هـ م 1910 rا. السنن للدارمي بتحقيق السيد عبد الله هاشم اليماني المدني.

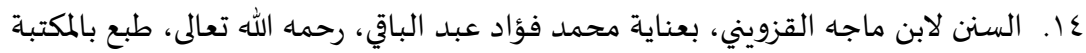

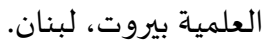
10. السنن للإمام للنسائي، تحقيق مكتب تحقيق التراث باث الإسلامي، مكتبة المؤيد بالرياض، ا

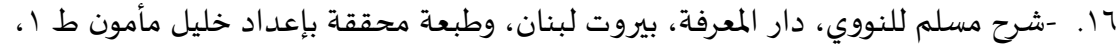
مان 1990 - ه 180 


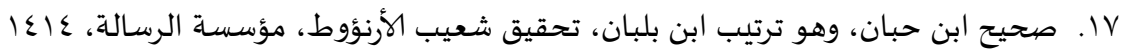

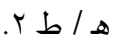

11. صحيح ابن خزيمة لأبي بكر محمد بن إسحاق بن خزيمة بتحقيق الأعظمي، المكتب

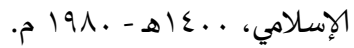

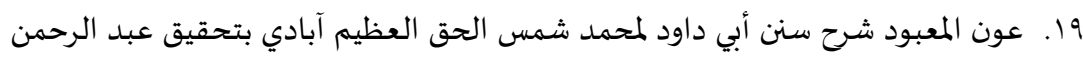

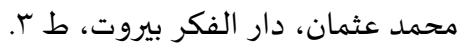

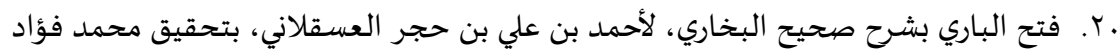
عبد الباقي، مكتبة الرياض الحديثة.

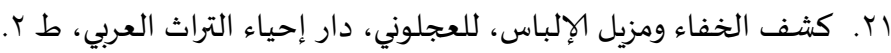

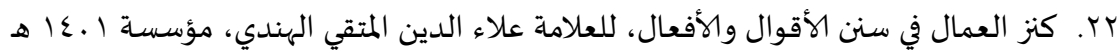

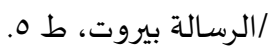

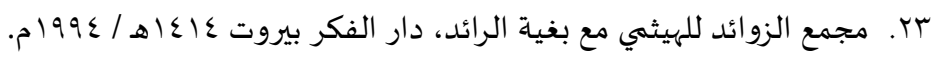

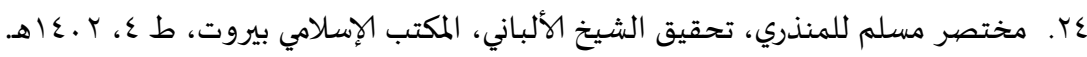

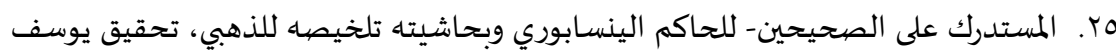
عبد الرحمن، دار المعرفة بيروت.

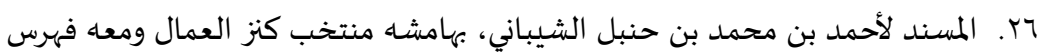
الألباني، المكتب الإسلامي بيروت.

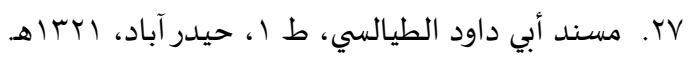

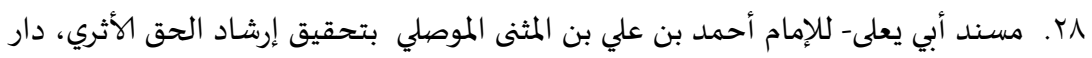

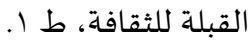

9. المعجم الكبير- لأبي القاسم سليمان بن أحمد الطبراني بتحقيق حمدي السلفي، نشر وزارة الأوقاف العراقية.

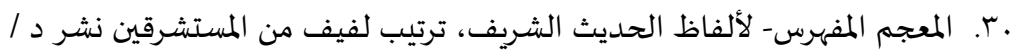

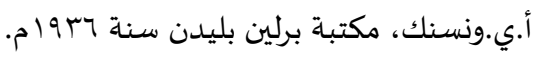

آس. المعجم المفهرس- لألفاظ القرآن الكريم، للأستاذ محمد فؤاد عبد المبند الباقي، المكتبة الإسلامية إستانبول.

rr. المعجم الوسيط، مجمع اللغة العربية، المكتبة الإسلامية، إستانبول تركيا.

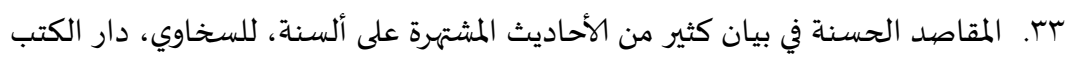

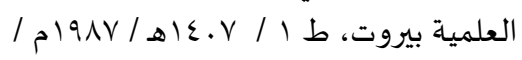


عَr. موارد الظمان إلى زوائد ابن حبان لنور الدين الهيثمي، بتحقيق محمد بن عبد الرزاق حمزة، دار الكتب العلمية، بيروت.

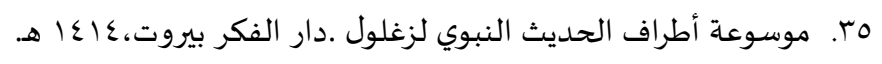

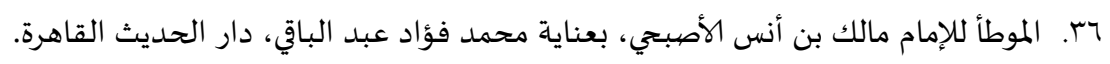
rV

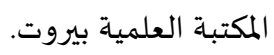


Fuad Sedić, $\mathrm{PhD}$

\section{MUSNAD BY IMAM ABU DAWUD AT-TAYALISI (133-204. H.G.-TJ. 750-819.GOD.)}

Abstract

Hadith or Sunnah is the second source of Islamic law. It was given importance since the time of Messenger Muhammad, p.b.u.h., through the chosen generation - the Companions, then Tabiin, and so to the present day. Preservation of hadith has passed through different periods. At first hadith were remembered by heart, but because of fear of forgetting, writing of the hadith began at a very early age. Procedures for gathering, recording and listening of the various Hadith collections has also undergone various phases and periods. The result is the emergence of various collections of hadith collections: Musnads, Muvetta'a, Musannafa, Sunan, Sahih, Jamia, Mustahrag, Mustadrak and various other collections in which their authors recorded what is faithfully transmitted from the Messenger, peace be upon him.

Musnad were among the first hadith collections, ie. collections of hadith in which the authors have classified the hadith recorded by the names of the companions who concerned hadith narrated from Muhammad, p.b.u.h., Authors would usually lined up the Companions based upon the advantages and merits that they have done in their lives. The usual sequence of companions in Musnad is to start with the ten companions who were promised Paradise, then the participants of the Battle of Badr, the Companions who were present at the contract Hudaybiya, etc..

Musnad of Abu Dawud At-Tayalisy belongs among the first Musnads which are preserved to this day. Its author and this Hadith collection ranks among the best known and most reliable book of its kind.

Keywords: the Hadith collections, Musnad, Abu Dawud At-Tayalisi, sanad 


$$
\text { الأستاذ الدكتور فؤاد سيديتش rr }
$$$$
\text { مسند أبي داود الطيالسي (سMا-ع .r هـ / أي •V-VI9 م) }
$$

\section{الخحلاصية}

يعتبر الحديث أو السنة مصدراً ثانياً من مصيادر الشريعة الإسلامية وكان هدف

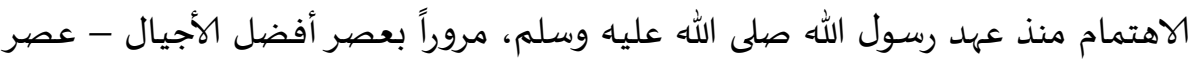

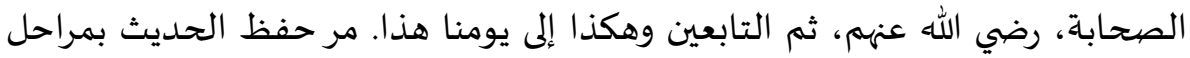
مختلفة: كان الحديث أول الأمر يُحْفَظ عن ظهر قلب، ولكن خشية نسيانها بدأ تلدوينه في وقت مبكر. عملية جمعه وتسجيله وتدوينه في المجموعات الحديثية المختلفة مرت كذلك بفترات ومراحل كان من نتيجة ذلك نشوء مجموعات حديثية مختلفة، مثل:

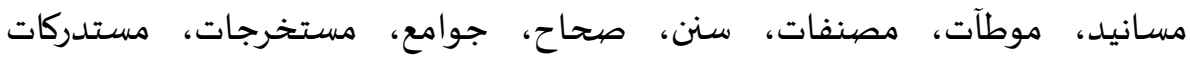

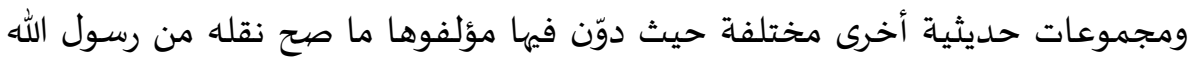
صلى الله عليه وسلم. كان مِن أول ما أُلِّف من مجموعات حديثلية مسانيد، أي مجموعات حديثية

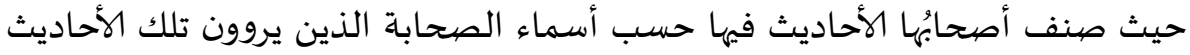

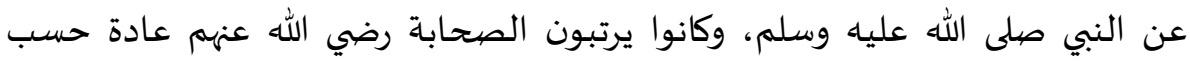
فضلهه والمساهمات التي أدلوا بها خلال حياتهم. ترتيب الصحابة المعتاد في المسانيد هو هو البدء بالعشرة المبشرين بالجنة، ثم من شهد منهم بلدراً، ثم من شهد منهم صلح الحديبية وما إلى ذلك. من أول المسانيد التي أُلِّفت وحُفظت إلى ذِلى يومنا هذا هو مسند أبي داود الطيالسي حيث يعتبر مؤلف المسند والمسـند نفسـه من أشهروأوثق الكتب من هذا النوع. الكلمات الرئيسـة: المجموعات الحـديثية، المسند، أبو داود الطيالسئ، السيند. 